\title{
PERAN INFRASTRUKTUR TRANSPORTASI DALAM PENGEMBANGAN PROVINSI LAMPUNG
}

\author{
Rahayu Sulistyorini \\ Fakultas Teknik Jurusan Sipil \\ Universitas Lampung \\ rahayu.sulistyorini@eng.unila.ac.id
}

\begin{abstract}
Transportation infrastructures have a very important role in encouraging the growth of a region and at the same time driving the growth of the community's economy in that region. This study aims to examine the influence of existing transportation infrastructure in Lampung Province, namely toll roads, executive terminal at Bakauheni Port, and Raden Inten II Airport, on the development of Lampung Province. The data used were obtained from a survey of traffic volume passing the toll road and interviews with a number of respondents at Bakauheni Seaport. The results obtained indicate that the longer the distance traveled, the greater the opportunity for travelers to use the toll road. As for goods transport, the choice to use the toll road is also influenced by the type of goods being transported. The combination of toll road transportation infrastructure and an executive terminal at Bakauheni Seaport also influences tourists to visit Lampung Province.
\end{abstract}

Keywords: transportation infrastructure; toll roads; executive terminal; seaport; airport.

\begin{abstract}
Abstrak
Prasarana transportasi mempunyai peran yang sangat penting dalam mendorong pertumbuhan suatu wilayah dan sekaligus pendorong tumbuhnya perekonomian masyarakat di wilayah tersebut. Studi ini bertujuan untuk mengkaji pengaruh infrastruktur transportasi yang ada di Provinsi Lampung, yaitu jalan tol, dermaga eksekutif di Pelabuhan Bakauheni, dan Bandara Raden Inten II, terhadap perkembangan Provinsi Lampung. Data yang digunakan diperoleh dari survei volume lalu lintas yang melalui jalan tol serta wawancara terhadap sejumlah responden di Pelabuhan Bakauheni. Hasil yang diperoleh menunjukkan bahwa semakin panjang jarak yang ditempuh, semakin besar peluang pelaku perjalanan untuk menggunakan jalan tol. Sedangkan untuk perjalanan barang, pilihan untuk menggunakan jalan tol juga dipengaruhi oleh jenis barang yang diangkut. Gabungan infrastruktur transportasi jalan tol dan dermaga eksekutif di Pelabuhan Bakauheni ikut memengaruhi wisatawan untuk berkunjung ke Provinsi Lampung.
\end{abstract}

Kata-kata kunci: infrastruktur transportasi; jalan tol; dermaga eksekutif; pelabuhan; bandara.

\section{PENDAHULUAN}

Prasarana dan sarana transportasi mempunyai peran yang sangat penting dalam mendorong pertumbuhan wilayah sekaligus sebagai pendorong tumbuhnya perekonomian masyarakat dengan tersedianya sarana dan prasarana, seperti jalan, terminal, pelabuhan laut, dan bandar udara. Menurut Restiana (2012), pembangunan prasarana ini diharapkan dapat menunjang kegiatan-kegiatan ekonomi yang terkait dengan keberadaan infrastruktur tersebut serta memungkinkan terjadinya peningkatan output, pendapatan masyarakat serta peningkatan Produk Domestik Regional Bruto (PDRB). 
Pembangunan infrastruktur jalan, berupa Jalan Tol Trans Sumatera (JTTS) dari Provinsi Lampung sampai Provinsi Aceh, saat ini masih pada tahap pembangunan di beberapa ruas. Untuk wilayah Provinsi Lampung, Ruas Bakauheni-Terbanggi Besar sudah mulai beroperasi pada bulan Maret 2019 dan pada bulan November 2019. Selain infrastruktur jalan, ada juga pembangunan infrastruktur transportasi laut, yaitu pembangunan Dermaga Eksekutif di Pelabuhan Bakauheni. Waktu tempuh kapal antardermaga ini kurang lebih 1 jam, dengan pelayanan dermaga dan kapal yang bersih. Bandara Radin Inten II, yang bertaraf internasional, juga menjadi pelengkap prasarana transportasi dalam mendukung pengembangan wilayah Provinsi Lampung.

Penelitian ini bertujuan untuk melihat perkembangan infrastruktur transportasi dalam pengembangan wilayah Provinsi Lampung. Data yang diambil adalah data survei primer, berupa perhitungan volume lalu lintas yang melalui jalan tol, serta wawancara terhadap sejumlah responden di Pelabuhan Bakauheni

\section{JALAN TOL TRANS SUMATERA}

Provinsi Lampung terletak di ujung Pulau Sumatera dan merupakan provinsi yang sangat dekat dengan pusat-pusat ekonomi dan kota-kota besar, seperti Jakarta dan wilayah Pertumbuhan ekonomi Jabodetabek. Untuk mencapai pusat-pusat ekonomi dan kota-kota besar tersebut, Provinsi Lampung dihubungkan oleh Pelabuhan Bakauheni, Bandara Raden Inten II, serta yang baru beroperasi saat ini, yaitu Jalan Tol Trans Sumatera (JTTS).

Panjang lintasan trase ruas jalan tol Bakauheni-Terbanggi Besar adalah sebesar 140,412 km. Jalan tol ini akan menyambung dengan rencana jalan tol Terbanggi BesarPematang Panggang-Kayu Agung. Kecepatan desain yang digunakan adalah 100 km/jam.

Pada tahap awal dibangun dengan konfigurasi 4 lajur 2 arah, dan pada tahap akhir akan mencapai 6 ajur 2 arah (Hutama Karya, 2018). Ruas jalan tol Bakauheni-Terbanggi Besar tersebut mempunyai 9 gerbang tol yang dapat diakses dari ruas jalan nontol, yaitu Gerbang Bakauheni, Gerbang Kalianda, Gerbang Sidomulyo, Gerbang Lematang, Gerbang Kota Baru, Gerbang Natar, Gerbang Gunung Sugih 1, Gerbang Gunung Sugih 2, dan Gerbang Terbanggi Besar (lihat Gambar 1). Kabupaten dan kota yang menjadi area cakupan layanan ruas jalan tol tersebut adalah Kabupataten Lampung Selatan, Kota Bandar Lampung, Kabupaten Pesawaran, dan Kabupaten Lampung Tengah. Jalan Mayjen H.M. Ryacudu adalah jalan akses penghubung antara Kota Bandar Lampung dengan Gerbang Tol Kota Baru. Jumlah pergerakan di jalan tersebut semakin meningkat dan jika diamati secara langsung, banyak sekali kendaraan berat yang melewatinya. Ruas jalan yang terkena dampak langsung pembangunan Ruas Jalan Tol Bakauheni-Terbanggi Besar adalah ruas-ruas jalan dan persimpangan terdekat, yang terhubung dengan rencana exit dan entrance jalan tol Bakauheni-Terbanggi Besar tersebut. 


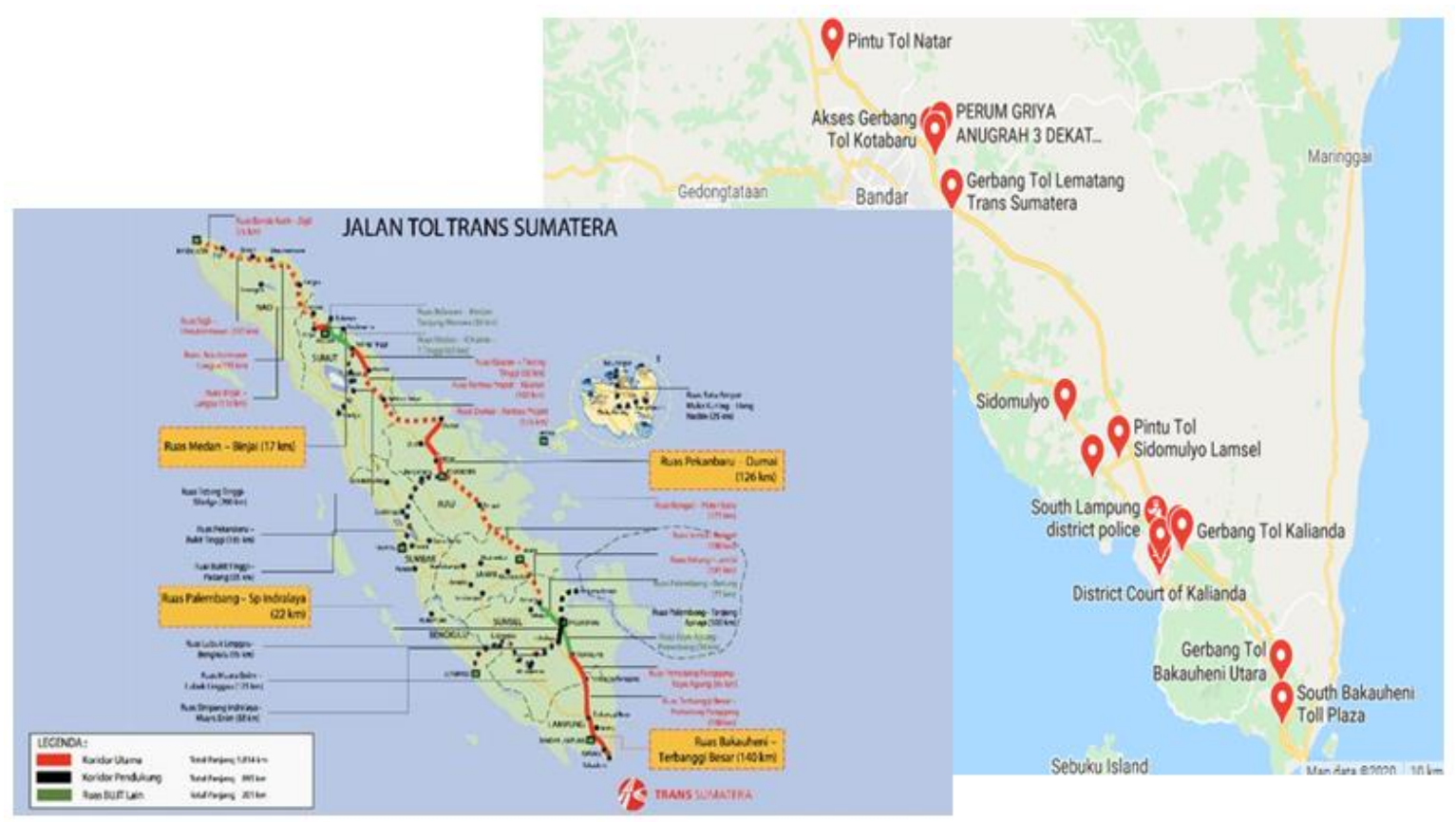

Gambar 1 Pintu Tol Ruas Tol Bakauheni-Terbanggi Besar

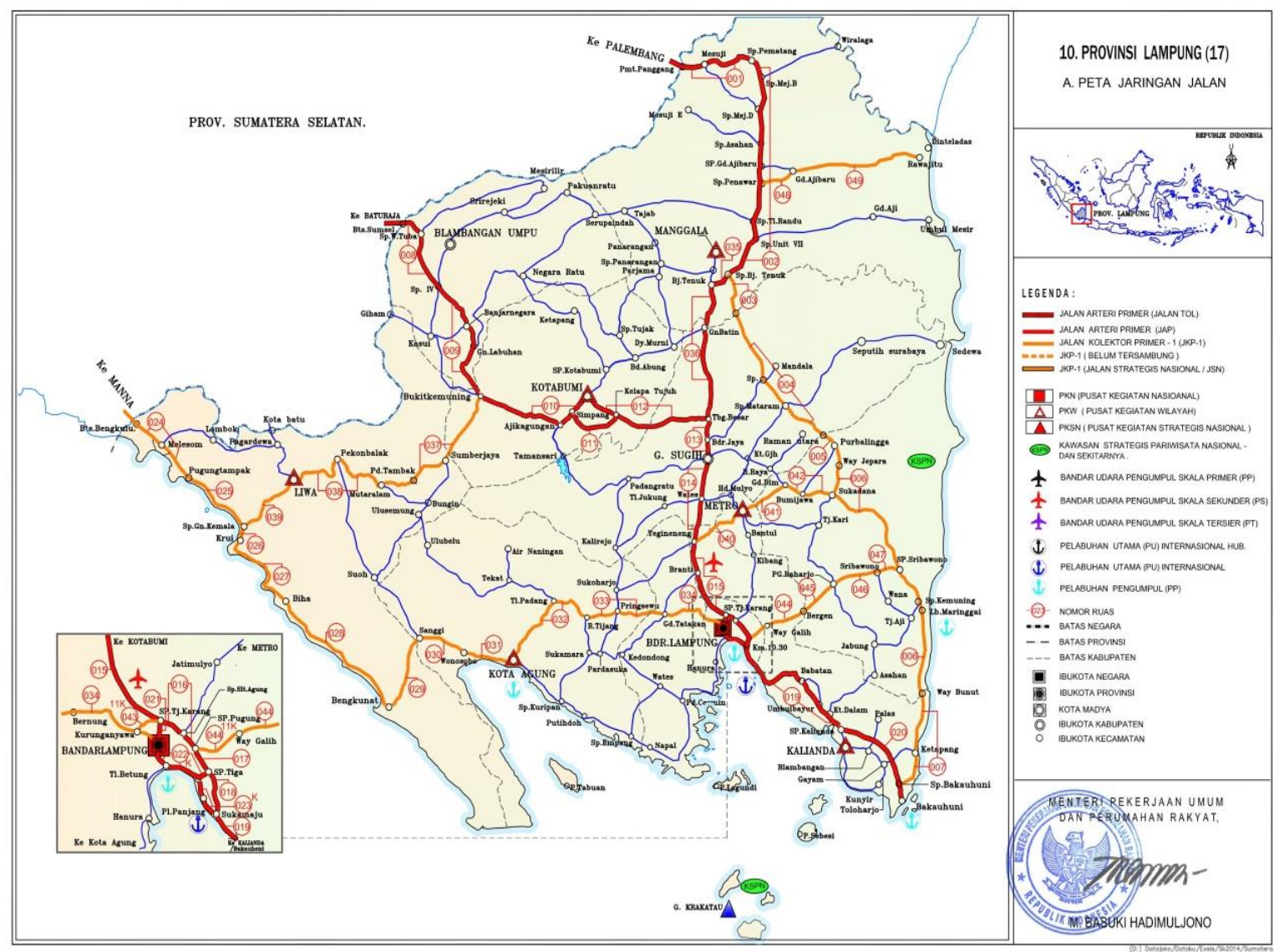

Sumber: Balai Besar Jalan Nasional Lampung (2018)

Gambar 2 Lokasi Pelabuhan Bakauheni Interkoneksi dengan JTTS dan Jalan Nasional 


\section{PELABUHAN BAKAUHENI}

Dalam Rencana Tata Ruang Wilayah Provinsi Lampung Tahun 2009-2029 disebutkan bahwa Pelabuhan Bakauheni dikembangkan untuk menunjang perkembangan aktivitas ekonomi wilayah regional dengan pelayanan mobilitas orang dan barang serta kebutuhan perikanan dan pariwisata. Pelabuhan ini memiliki peran penting dalam transportasi laut serta pendistribusian barang dan jasa antara Pulau Jawa dan Pulau Sumatera, sehingga menjadikan Pelabuhan Bakauheni sebagai salah satu pelabuhan teramai di Indonesia (Armanto, 2018).

Pelabuhan Bakauheni memiliki fungsi pokok melayani kegiatan angkutan penyeberangan, dengan jangkauan layanan antarprovinsi. Dengan adanya Pelabuhan Bakauheni dan didukung posisi Provinsi Lampung yang strategis, menjadikan Provinsi Lampung sebagai pintu gerbang Pulau Sumatera sekaligus tempat limpahan dan daerah transit kegiatan ekonomi antar Pulau Sumatera dan Pulau Jawa (Pemerintah Provinsi Lampung, 2010).

Saat ini Pelabuhan Bakauheni memiliki dermaga eksekutif. Dengan adanya dermaga ini, pendistribusian barang dan penumpang menuju Pulau Jawa dapat menjadi lebih cepat, sehingga memberikan dampak yang besar terhadap perkembangan yang ada di Pulau Sumatera, khususnya di Provinsi Lampung. Untuk menuju Pelabuhan Bakauheni, terdapat 2 pilihan rute, yaitu melalui JTTS ruas Bakauheni-Terbanggi Besar dan melalui jalan nasional yang telah ada (lihat Gambar 2). Untuk mencapai Pelabuhan Bakauheni, kendaraan yang menggunakan jalan tol akan melalui Pintu Tol Kota Baru-Bakauheni Selatan, yang menghubungkan Kota Bandar Lampung dan Pelabuhan Bakauheni.

\section{PROPORSI PENGGUNA JALAN TOL}

Berdasarkan hasil analisis, diketahui bahwa jarak rata-rata yang ditempuh pengguna rute adalah 87,4 km dengan waktu tempuh rata-rata sebesar 1 jam 45 menit. Jarak yang cukup jauh tersebut menyebabkan biaya transportasi menjadi semakin besar (Indrareni dan Rakhmatulloh, 2013).

Pada studi ini dilakukan penyebaran kuesioner menggunakan metode Stated Preference, dengan pembagian proporsi yang berbeda antara pengguna jalan yang menggunakan angkutan penumpang dan pengguna jalan yang menggunakan angkutan barang. Penyebaran kuesioner secara online ditujukan kepada pelaku perjalanan yang melakukan perjalanan dengan menggunakan angkutan penumpang, sedangkan penyebaran kuesioner secara offline ditujukan kepada pelaku perjalanan yang melakukan perjalanan dengan menggunakan angkutan barang. Penentuan sampel dilakukan dengan cara Proportionate Stratified Random Sampling, yaitu teknik pengambilan sampel untuk populasi yang tidak homogen dan berstrata secara proporsional (Triyono, 2003). Sampel yang diambil merupakan pengendara atau responden yang melalui rute kajian penelitian dan memiliki kriteria sebagai berikut:

1) Responden menggunakan kendaraan roda empat atau lebih. 
2) Jenis kendaraan yang digunakan merupakan jenis angkutan barang dan/atau penumpang.

3) Responden memiliki tujuan perjalanan Kota Bandar Lampung-Pelabuhan Bakauheni.

4) Responden sudah pernah menggunakan kedua rute yang diteliti, yaitu Jalan Nasional Kota Bandar Lampung-Pelabuhan Bakauheni dan JTTS ruas Bakauheni Terbanggi Besar melalui Pintu Tol Kota Baru-Bakauheni Selatan.

Model pemilihan rute yang digunakan untuk memodelkan pemilihan rute oleh penumpang pada studi ini adalah model logit binomial. Selanjutnya, dilakukan analisis dengan bantuan perangkat lunak Minitab, untuk mengetahui model peluang pemilihan rute perjalanan Kota Bandar Lampung-Pelabuhan Bakauheni.

Dua alternatif pilihan rute menuju Kota Bandar Lampung-Pelabuhan Bakauheni adalah melewati jalan nasional (n) dan melewati jalan tol (t). Dengan demikian model logit binomial dapat dinyatakan sebagai berikut:

$$
p_{t}^{i}=\frac{\exp \left(U_{t}\right)}{\exp \left(U_{t}\right)+\exp \left(U_{t}\right)} \text { atau } p_{t}^{i}=\frac{1}{1+\exp \left(U_{t}\right)}
$$

dengan:

$p_{t}^{i}=$ Peluang seseorang memilih jalan tol.

$U_{t}=$ Nilai utilitas jalan tol terhadap jalan nasional.

Semakin besar jarak yang ditempuh, peluang pemilihan jalan tol semakin mendekati 1 , yang artinya pengguna rute akan semakin lebih memilih menggunakan jalan tol bila jarak yang ditempuh semakin besar, dan sebaliknya untuk jalan nasional (lihat Tabel 1 dan Gambar 3). Jarak rata-rata yang ditempuh pelaku perjalanan untuk melakukan 1 kali perjalanan Kota Bandar Lampung-Pelabuhan Bakauheni adalah 87,4 km dengan waktu tempuh ratarata adalah 104,7 menit dan biaya rata-rata yang dikeluarkan untuk 1 kali perjalanan, termasuk biaya bahan bakar dan biaya tak terduga lainnya, adalah sebesar Rp171.460,00.

Pelaku perjalanan yang menggunakan angkutan barang untuk melakukan perjalanan Kota Bandar Lampung-Pelabuhan Bakauheni memiliki beberapa karakteristik berbeda. Pengguna jalan dipengaruhi oleh muatan atau jenis barang yang sedang dan akan dibawa. Jenis barang atau muatan yang tidak dapat bertahan lama, seperti buah dan sayur, serta jenis barang atau muatan yang dapat bertahan lama, seperti barang elektronik, menjadi pertimbangan bagi pengguna jalan dalam memlih rute yang akan digunakan. Hal ini yang menjadi pembeda antara pengguna rute yang menggunakan angkutan penumpang dan pengguna rute yang menggunakan angkutan barang pada saat melakukan perjalanan Kota Bandar Lampung-Pelabuhan Bakauheni. 
Tabel 1 Sensitivitas Perubahan Jarak Tempuh

\begin{tabular}{rcc}
\hline \multirow{2}{*}{$\begin{array}{c}\text { Jarak } \\
(\mathrm{km})\end{array}$} & Peluang Jalan Tol & Peluang Jalan Nasional \\
\cline { 2 - 3 } $\mathrm{P}_{\mathrm{T}}=\exp \left(\mathrm{U}_{\mathrm{T}}\right) /\left(1+\exp \left(\mathrm{U}_{\mathrm{T}}\right)\right)$ & $\mathrm{P}_{\mathrm{N}}=1-\mathrm{P}_{\mathrm{T}}$ \\
\hline 0 & 0,034489568 & 0,965510432 \\
10 & 0,059468409 & 0,940531591 \\
30 & 0,100652094 & 0,899347906 \\
40 & 0,165342829 & 0,834657171 \\
50 & 0,259609341 & 0,740390659 \\
60 & 0,382960781 & 0,617039219 \\
70 & 0,523482711 & 0,476517289 \\
80 & 0,660382673 & 0,339617327 \\
90 & 0,774866989 & 0,225133011 \\
100 & 0,858998906 & 0,141001094 \\
110 & 0,915134236 & 0,084865764 \\
120 & 0,950216204 & 0,049783796 \\
130 & 0,971251504 & 0,028748496 \\
140 & 0,98355254 & 0,01644746 \\
150 & 0,990640872 & 0,009359128 \\
160 & 0,994690849 & 0,005309151 \\
170 & 0,996993597 & 0,003006403 \\
180 & 0,998299278 & 0,001700722 \\
190 & 0,999038448 & 0,000961552 \\
200 & 0,999456534 & 0,000543466 \\
\hline
\end{tabular}

Sumber: Syieda (2020)

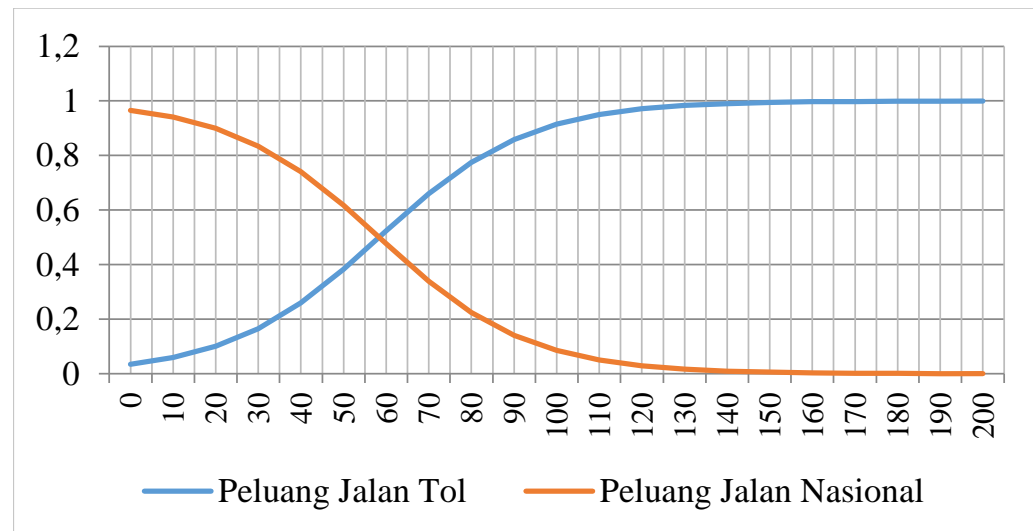

Sumber: Syieda (2020)

Gambar 3 Peluang Pemilihan Rute Berdasarkan Perubahan Jarak Tempuh

\section{PENGARUH INFRASTRUKTUR TRANSPORTASI}

Pertumbuhan ekonomi, yang tidak terlepas dari transportasi, menyebabkan adanya permintaan akan pengadaan, perbaikan, dan pelayanan prasarana transportasi (Harum dan Sutriani, 2017). Pada studi ini diteliti 3 infrastruktur transportasi, yaitu Jalan Tol Trans Sumatera (X1), Dermaga Eksekutif Pelabuhan Bakauheni (X2), dan Bandara Raden Inten II (X3). Variabel Minat Kunjungan Wisatawan (Y) merupakan pernyataan sikap responden tentang minat berkunjung, yang berkaitan dengan ketersediaan, kualitas, akses dan konek- 
tivitas infrastruktur transportasi, yaitu jalan tol, dermaga eksekutif, dan bandara, di Lampung Selatan. Hasil Nilai $\mathrm{R}^{2}$ dapat dilihat pada Tabel 2.

\begin{tabular}{cc}
\multicolumn{2}{c}{ Tabel 2 Matriks Regresi Linier } \\
\hline Variabel X & $\mathrm{R}^{2}(\%)$ \\
\hline X1 & 34 \\
X2 & 31 \\
X3 & 14 \\
X1X2 & 40 \\
X1X3 & 31 \\
X2X3 & 28 \\
X1X2X3 & 36 \\
\hline
\end{tabular}

Dari hasil analisis regresi, nilai $\mathrm{R}^{\mathbf{2}}$ yang paling berpengaruh dengan minat kunjung kembali wisatawan adalah gabungan antara infrastruktur jalan tol dan dermaga eksekutif. Hal ini berarti bahwa adanya kedua infrastruktur tersebut meningkatkan minat lain, yang mempengaruhi besarnya minat kunjung kembali wisatawan. Faktor lain bisa dipengaruhi oleh daya tarik tempat wisata, fasilitas penunjang tempat wisata, pengelolaan tempat wisata, masyarakat sekitar, aksesibilitas tempat wisata, promosi dan kebijakan pemerintah daerah dalam meningkatkan wisata daerah.

Tabel 3 Hubungan antara Variabel X1 dan X2

\begin{tabular}{llll}
\hline & Value & df & Asymp. Sig \\
\hline Pearson Chi-square & 8.878 & $9(16.918)$ & 0,449 \\
Contingency Coefficient & 0,283 & & \\
Nof Valid Cases & 102 & & \\
\hline
\end{tabular}

Berdasarkan hasil uji chi-square, yang terdapat pada Tabel 3, nilai chi-square hitung, sebesar 8.878, lebih kecil daripada chi-square tabel, yaitu sebesar 16.918, dan nilai sig. sebesar 0,449, yang lebih besar daripada 0,05. Dengan demikian dapat disimpulkan bahwa tidak terdapat hubungan antara Ketersediaan Infrastruktur Dermaga Eksekutif (X2) dengan Akses dan Konektivitas Infrastruktur Jalan Tol (X1). Nilai koefisien kontingensi adalah 0,283 , yang menandakan hubungan antarvariabel tersebut yang lemah.

\section{KESIMPULAN}

Infrastruktur jalan tol di Provinsi Lampung, yaitu Ruas Bakauheni-Terbanggi Besar, sudah mulai pada tahun 2019. Selain infrastruktur jalan tol, terdapat pulau infrastruktur transportasi laut, yaitu Dermaga Eksekutif di Pelabuhan Bakauheni, dan infrastruktur transportasi udara, yaitu Bandara Radin Inten II, yang semuanya ikut mendukung pengembangan wilayah Provinsi Lampung.

Pada studi ini dikaji peran infrastruktur transportasi terhadap pengembangan wilayah Provinsi Lampung. Hasil yang diperoleh menunjukkan bahwa Semakin besar jarak yang ditempuh, semakin besar peluang pelaku perjalanan untuk menggunakan jalan tol. Untuk 
perjalanan barang, pemilihan untuk melewati infrastruktur jalan tol juga dipengaruhi oleh jenis barang yang dibawa.

Gabungan infrastruktur yang tersedia juga memengaruhi kunjungan wisatawan di Provinsi Lampung. Minat untuk melakukan kunjungan kembali wisatawan ke Provinsi lampung dipengaruhi oleh gabungan antara infrastruktur jalan tol dan dermaga eksekutif di Pelabuhan Bakauheni.

\section{UCAPAN TERIMA KASIH}

Ucapan terima kasih diberikan pada PT Hutama Karya, serta Lana dan Meiriska, Mahasiswi Magister Teknik Sipil Unila, yang telah memberikan data sekunder, serta Syieda, mahasiswi ITERA, yang telah mengolah data.

\section{DAFTAR PUSTAKA}

Armanto, Y.N. 2018. Pembebanan Jaringan Jalan dari Pintu Keluar Pelabuhan Bakauheni dengan Adanya Jalan Tol Trans Sumatera. Tugas Akhir (tidak dipublikasikan). Bandar Lampung: Jurusan Teknik Sipil, Universitas Lampung.

Balai Pelaksanaan Jalan Nasional (BPJN) Lampung. 2018. Peta Jaringan Jalan Provinsi Lampung. Bandar Lampung.

Harum, M. dan Sutriani. 2017. Pengaruh Pembangunan Jalan Tol Sutami terhadap Nilai Lahan di Sekitarnya. Jurnal UIN Alauddin, 4 (1): 66-73.

Hutama Karya (Persero), PT. 2018. Laporan Analisis Dampak Lalu Lintas Pembangunan Ruas Jalan Tol Bakauheni-Terbanggi Besar. Jakarta.

Hutama Karya (Persero), PT. 2019. Data Jumlah Kendaraan Keluar Masuk di Pintu Tol Kalianda. Jakarta.

Indrareni, A. dan Rakhmatulloh, A.R. 2013. Pengaruh Pergerakan Pekerja Komuter terhadap Pola Konsumsi di Kecamatan Kaliwungu. Jurnal Teknik PWK, 2 (4): 927-937.

Pemerintah Kota Bandar Lampung. Rencana Program Investasi Jangka Menengah Bidang Cipta Karya Kota Bandar Lampung Tahun 2012-2016. Bandar Lampung.

Pemerintah Provinsi Lampung. 2010. Peraturan Daerah Provinsi Lampung Nomor 1 Tahun 2010 Tentang Rencana Tata Ruang Wilayah (RTRW) Provinsi Lampung Tahun 2009 Sampai dengan Tahun 2029. Bandar Lampung.

Restiana, D. 2012. Peranan Investasi Pembangunan Infrastruktur Transportasi dalam Perekonomian Daerah: Studi Kasus Bandara Internasional Sepinggan-Kalimantan Timur. Skripsi (tidak dipublikasikan). Bogor: Institut Pertanian Bogor.

Syieda, D.P. 2020. Peluang Pemilihan Rute Perjalanan Kota Bandar Lampung-Bakauheni. Tugas Akhir (tidak dipublikasikan). Lampung Selatan: Institut Teknologi Sumatera. Triyono. 2003. Teknik Sampling dalam Penelitian. Penataran Analisis Data Penelitian bagi Dosen PTS Kopertis XI. Palangka Raya: Universitas Palangka Raya. 